\title{
Sport a školní pohybové aktivity v inkluzi žáků se speciálními vzdělávacími potřebami
}

\section{Special Needs Students Inclusion through the Sport and School Physical Activities}

\author{
Exseil Streda ${ }^{1}$, Střední škola Euroinstitut, Neprobylice
}

\begin{abstract}
Abstrakt
Oblasti vzdělávání, sportu a volnočasových aktivit je propojena v této práci s inkluzí žáků se speciálními vzdělávacími potřebami. Vytvářen pro ně je v rámci speciální střední školy program, který pomocí školních a mimoškolních pohybových aktivit přispívá k integraci a inkluzi postižených žáků mezi žáky a sportovce zdravé. Mimoškolní aktivity jsou zejména u jednoletých a dvouletých praktických škol součástí kurikula v rámci rámcových vzdělávacích programů (RVP) Ministerstua školství, mládeže a tělovýchovy. Proto je součástí zaměření také na mimoškolní pohybové aktivity ve vztahu k inkluzivním snahám.

Program je založený nejen na účasti školy a jejich žáků, počítá s přirozeným zapojením rodičù nebo opatrovníkủ žáků, ale i ústavů sociální péče, jejichž služeb žáci využívají. Kromě všech jmenovaných stran program zahrnuje zdravé sportovce, kteří se programu zúčastňují nejčastěji na základě komunitní blízkosti.
\end{abstract}

\section{Klíčová slova}

přizpưsobené pohybové aktivity, inkluze, školní pohybové aktivity, mimoškolní pohybové aktivity, speciální vzdělávací potřeby

\section{Abstract}

We link the areas of education, sports and leisure activities with the inclusion of special needs. Creating of program for them within a special secondary school is the main goal. School physical activities and extracurricular ones contribute to the integration and inclusion of disabled pupils. Special schools (practical 1 year and 2 years special schools) have an extracurricular education program included in the Framework Educational Programs (FEP) of the Department of Education, Youth and Sports. Therefore, this work also deals with extracurricular physical activities in relation to inclusive efforts.

\section{Keywords}

special needs, inclusion, school physical activities, FEP

\section{1. Úvod}

Bez ohledu na zdravou populaci či jedince se speciálními vzdělávacími potřebami má přiměřená pohybová aktivita pozitivní vliv na lidský organismus. Př́íznivý vliv má i na socializaci jedince a vývoj jeho osobnosti, schopnost komunikace nebo empatie. V pobytových sociálních službách jsou tyto skutečnosti reflektovány a různé nabídky pohybových aktivit pro handicapované jedince jsou součástí posílení úlohy klienta vyplývající dokonce z legislativy v sociální sféře (Zákon 108/2006 Sb.). Tak je třeba přistupovat k žákům, kteří do školy z pobytových sociálních zařízení docházejí.

Autorka příspěvku pracuje ve škole, která vzdělává žáky s kombinovaným postižením (Střední škola Euroinstitut). Otázka inkluze žáků se speciálními vzdělávacími potřebami zasahuje zcela nevyhnutelně do oblasti profesních zájmů. Protože sport a vůbec pohybová aktivita je vnímána jako podstatná, bohužel často výrazně podceňovaná a zanedbávaná součást života zdravých i postižených. 
Sport a pohybové aktivity mají kromě nesporně kladného vlivu na tělesné i duševní zdraví výrazný potenciál na poli inkluze. A nejde výhradně o sporty orientované výhradně na výkon. V případě žáků se speciálními vzdělávacími potřebami jde spíše o možnost pravidelného pohybu, o možnost dosáhnout ocenění a uznání za vynaloženou námahu a snahu, o možnost zažít pocity uznání a uspokojení z podaného výkonu, a to bez ohledu na to, zda je sportovcem žák se speciálními vzdělávacími potřebami, nebo ne.

Euroinstitut má specifické podmínky: většina žáků je zároveň klienty ústavơ sociální péče, aț už se jedná o domovy pro osoby se zdravotním postižením, domovy se zvláštním režimem nebo třeba chráněná bydlení. Ve všech případech je třeba do spolupráce ve vzdělávacím procesu zahrnout kromě žáka a jeho rodičů nebo opatrovníků také právě ústavy, které sociální péči poskytují. Větší počet účastníků v celém procesu s sebou může nést pozitivní, ale i negativní dopady.

\section{Teoreticko-historický rámec}

Již počátkem minulého století poukazoval profesor Karel Weigner (1884-1945) na význam tělovýchovy jako podstatné složky kultury národa. Jako lékař dokázal rozpoznat rizika rozvoje technických disciplín, které způsobují jednostranné rozvržení práce a oslabení fyzické kondice (Weigner 1916). Nedostatečnou rozmanitost pohybu v současnosti provází sedavý životní styl, který bývá u postižených často ještě umocněn základním handicapem. Tento styl, který je charakterizován sníženou úrovní pohybové aktivity a výkonnosti vyjadřuje pojem hypokinetický. Kompenzace tohoto způsobu života je důležitým úkolem školy. Tuto úlohu je třeba přijímat v rámci společenského managementu. Tělesná výchova žáků v rozsahu několika hodin povinného předmětu týdně musí být doplněna o pohybové aktivity v dalš́i výuce, ale i v celém chodu školy (Procházka 2017). Přirozeně i mimo školu.

Pohybové aktivity pro postižené souvisí se specifiky heterogenní skupiny handicapovaných s mnoha odlišnnostmi od intaktní společnosti. Pro úspěšné a efektivní vykonávání funkce se musí pedagog v problematice handicapovaných dobře orientovat. Musí znát nejen konkrétní druhy postižení nebo kombinace postižení, ale i z nich vyplývající nároky a omezení a zdravotní komplikace. Je třeba také brát v úvahu věk handicapovaných.

Pohybové aktivity postižených žáků se obvykle rozdělují na několik následujících skupin (Levitová a Hošková 2015):

1. Léčebná tělesná výchova je aktivita určená pro jedince s pozměněným zdravotním stavem. Předepisuje lékař, realizuje lékař nebo fyzio- či kinezioterapeut.

2. Zdravotní tělesná výchova je zaměřená na handicapované se zdravotním oslabením, bývá organizována v rámci vzdělávání, v zájmových sdruženích nebo sportovních oddílech a vedou ji pedagogové s odpovídajícím vzděláním, profesionální cvičitelé a trenéři.

3. Habituální pohybová aktivita zahrnuje pohybové činnosti všednodenního života jako chůzi, práci na zahradě, úklid nebo nákup. Důležité je vytvoření pohybových vzorců a režimů.

4. Rekreační sport postižených zahrnuje pohybové aktivity, které tvoří složku volného času a životního stylu, např́́klad plavání, turistika, cyklistika nebo veškeré druhy kolektivních sportů.

5. Přizpůsobené pohybové aktivity zahrnují soutěžní klání postižených v disciplínách, umožňujících plné zapojení handicapovaných sportovců.

6. Psychomotorické terapie, které vycházejí z těsného vztahu mezi psychickým a motorickým prožíváním.

7. Pedagogické terapie na pomezí pohybových a expresivních terapií (taneční terapie či dramaterapie), př́ipadně pohybové terapie na průsečíku s terapiemi za asistence zvířete (hippoterapie), cílené pohybové rehabilitace jako terapie hrou či smysluplné terapeutické zaměstnání (ergoterapie).

\subsection{Znalostní management}

Koncepční rámec pohybových aktivit pro postižené vyžaduje mezioborovou spolupráci jako přirozenou a potřebnou součást při práci s klientem, ve škole s žákem. Využívá poznatky z medicíny, pedagogiky a psychologie. Požaduje, aby se specializovaný pedagog na základě všech uvedených poznatků snažil posilovat pozitivní zdroje zvládání, podporovat kompetence člověka, který má problémy s orientací, rozhodováním, vytvářením vztahů, komunikací a podobně. Pedagog se zabývá procesem habilitace, zatímco pracovník sociálních služeb poskytuje klientovi sociální rehabilitaci.

Úmluva o právech osob se zdravotním postižením, přijatá OSN v roce 2007, v článku 26 říká: Pro tento účel je zapotřebí zřizovat komplexní habilitační a rehabilitační služby a programy, a to především v oblastech 
zdravotnictví, zaměstnanosti, vzdělávání a sociálních služeb pro dosažení a udržení maximální možné samostatnosti a pro uplatnění tělesné, duševní, sociální a profesní schopnosti v plné míře. Habilitací a rehabilitací lze dosáhnout úplného začlenění a zapojení do veškerých oblastí života (Sdělení MZV...2010).

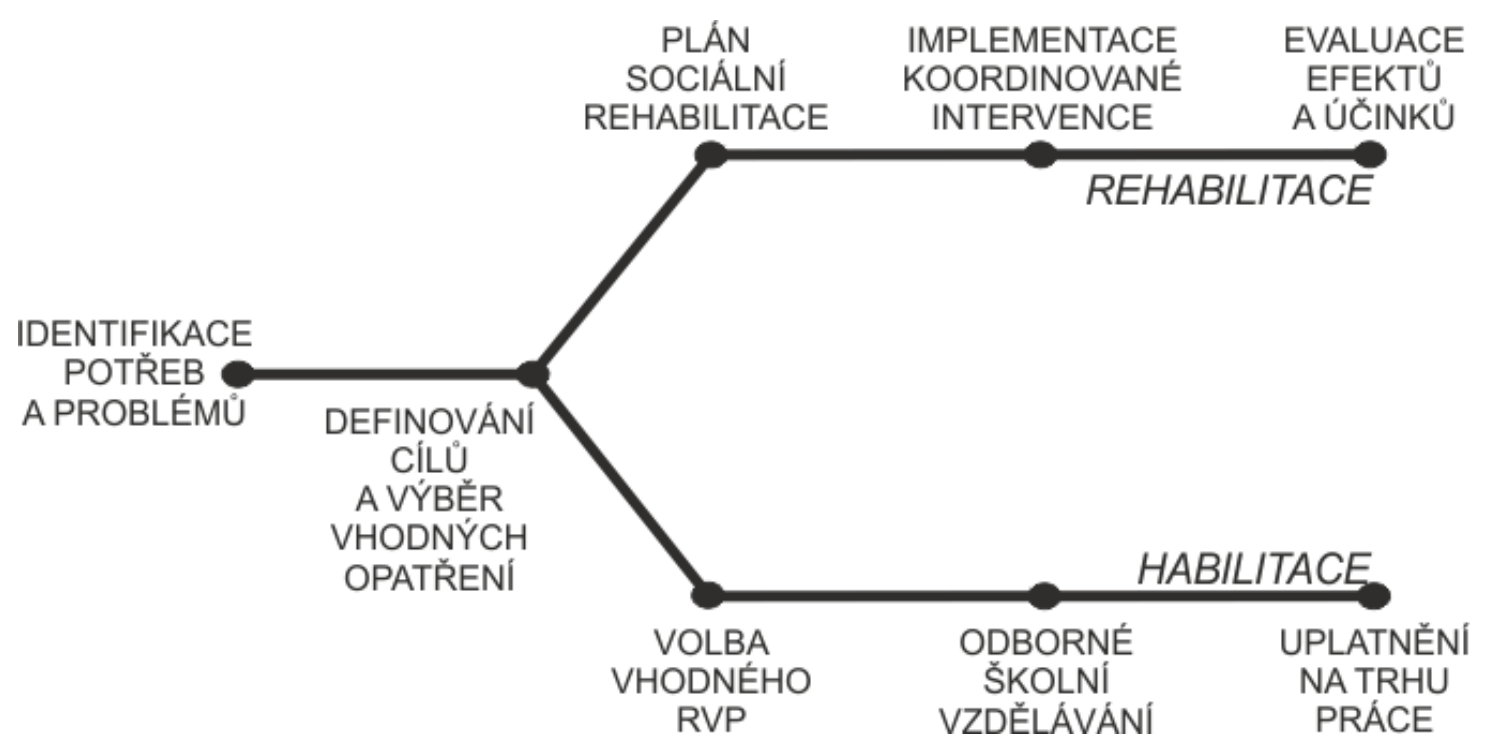

Obrázek 1: Základní model procesu habilitace a rehabilitace, zdroj: vlastní zpracování

Habilitace představuje proces získávání nových schopností a dovedností. Takových, které osoba předtím nikdy neměla. Pojem habilitace je spojován především se školským vzděláváním postižených. Oproti tomu rehabilitace patří hlavně do sociální sféry. Pojem označuje opětovné získávání schopností a zručností. Takových, které už člověk měl předtím získané. Habilitace všeobecně představuje vzdělávání a podporu a je určená především pro jedince s vrozenou nebo získanou nemocí, zdravotním postižením nebo se sníženými schopnostmi.

Speciální pedagog může působit v heterogenní třídě za splnění určitých požadavků. Nezbytný je proinkluzivní etický postoj, trojitý kontakt, reflexe, administrativa profesionálního výkonu a v neposlední řadě negace profesionalismu. Proinkluzivní etický postoj je viditelný ve výchovně vzdělávací činnosti speciálního pedagoga se všemi žáky. Speciální pedagog musí být schopen přijmout dítě takové, jaké je, včetně jeho nedostatků, zároveň má k němu úctu. S dítětem začne pracovat na jeho aktuální úrovni a snaží se o to, aby dítě přijali jeho vrstevníci, učí ho rozhodovat se, plánovat (Černá 2015). Umožňuje dítěti aktivně tvořit a předkládá umělecké zážitky, podporuje ho ve výtvarné a hudební oblasti. Učitel je součástí výchovy a pedagogické terapie.

\subsection{Souvztažnost pohybových aktivit ve škole}

Zatímco přiměřená pohybová činnost s sebou přináší pozitivní a stimulační dopady na lidský organismus a jeho zdraví, nepřiměřený, jednostranně zaměřený nebo nevhodně prováděný pohyb působí na jedince negativně. To platí pro majoritní společnost stejně jako pro handicapované jedince.

Současný způsob života se vyznačuje především nedostatkem pohybu a stále se prodlužujícím časem, který je tráven v sedě. Snahy o kompenzaci negativních vlivů takového způsobu života se objevují na úrovni vzdělávacích institucí, sociálních zařízení i veřejnosti. Termín pohybové aktivity lze použít jako označení pro aktivity v oblasti řízení pohybových a sportovních aktivit pro postižené na různých úrovních.

Školní tělovýchova chce kromě zvyšování tělesné zdatnosti dosáhnout také osvojování správných návyků v souvislosti s pohybem. Především usiluje o vytvoření pozitivního vztahu k pohybovým aktivitám a 0 zahrnutí pohybových aktivit do každodenního života handicapovaných. Oproti tomu sociální služby plní spíše roli udržovací a preventivní, získaný návyk svých klientů se snaží udržovat a k pohybové aktivitě přistupovat jako k účinné prevenci zdravotních komplikací spojených s nedostatkem pohybu.

Pohybové aktivity pro handicapované řízené centrálně mohou plnit kromě primárního účelu také úlohu inkluzivní a socializační. Přizpůsobené pohybové aktivity mají potenciál zahrnout handicapované sportovce do majoritní společnosti. 
Zdravotně orientovaná tělovýchova se zaměřuje do různých oblastí a využívá proto různé postupy. K nejběžnějším patří:

• zdravotní tělesná výchova,

- pohybové vzorce a režimy,

- přizpưsobené pohybové aktivity a sporty,

- léčebná tělesná výchova.

Zdravotně orientovaná tělovýchova si klade za cíl vytváření pozitivního vztahu postižených žáků k pohybové činnosti. Ti by měli přiměřeně svému postižení poznat svoje pohybové možnosti a nabýt pohybové potřeby. Léčebná pedagogika považuje pohyb za prostředek výchovy. "Cvičím pro zdraví a baví mě to" je název publikace autorky z Masarykovy univerzity (Šeráková 2009), který může být zároveň motem tělovýchovných metod v léčebné pedagogice.

\section{Význam organizování pohybových aktivit pro žáky se SVP}

Kompenzaci negativních vlivů současného životního stylu s nedostatkem pohybu není možné ponechat pouze na dvou až třech vyučovacích hodinách povinné tělesné výchovy týdně (Procházka 2017). Školy významně zasahují do režimu dětí, dospívajících, ale i dospělých postižených žáků. Pohyb by měly přenášet také do další výuky i do celého chodu školy. Pravidelná pohybová činnost s dostatečným pobytem v př́rodě je jednou z ideálních podmínek pro zdravý vývoj dítěte. Škola hraje v procesu významnou roli. Úkolem školy není jen vychovávat a vzdělávat žáky. Je třeba také vycházet vstříc i životním potřebám žáků. K základním potřebám dítěte a zároveň i ke stěžejním součástem péče o zdraví patří pohybová činnost (Mužík a Krejčí 1997). Tělovýchovným aktivitám se má věnovat každé dítě minimálně hodinu denně, to se týká jak zdravých, tak postižených (WHO 2020). Jakkoli se uvedený čas může zdát krátký, společnost, která není příliš aktivní, může mít s vyplněním takové doby pohybem problémy. I přes tuto skutečnost se objevují požadavky na navýšení doporučené doby, a to především z důvodu nedostatečnosti aktuálně definované doporučené doby.

Četné funkční poruchy pohybového systému mohou být původcem změn psychosomatických a následně morfologických (Levitová a Hošková 2015). Postižení žáci potřebují získávat zdravé pohybové návyky v rámci preventivních cvičení. Současně je důležitá výuka uspořádání denního a týdenní režimu. Jak uvádějí naši přední tělovýchovní pedagogové docent Vladislav Mužík (*1952) a Milada Krejčí (*1956): dítě, které není vedeno k přiměřenému dělení času mezi povinnosti, zábavu a nezbytnou pohybovou aktivitu, je obvykle poznamenáno na celý život a správné návyky pro racionální využití volného času získává jen velmi obtížně (Mužík a Krejčí 1997). To platí u dětí zdravých i postižených bez rozdílu.

\subsection{Organizace tělovýchovy postižených žáků}

Jádrem rozhodovacího procesu je výběr nejvhodnějšíi varianty. Pedagog musí před zahájením vyučování, ale i v jeho průběhu zvážit své záměry. Jde o kontinuálně probíhající proces, který má ve svém středu postiženého žáka, a to jako proměnlivý, neustále se v čase měnící a do jisté míry nepředvídatelný prvek. Je v podstatě nemožné predikovat detailně reakci organismu postiženého jedince na zátěž. Obtížné může být i odhadnutí času a počtu opakování nutného k úspěšnému osvojení dovedností a schopností. Na přípravě záleží, nelze ji podceňovat.

Ovlivňující proces jako nejvýhodnější strategie řízení učebních činností postižených žáků je založen na komunikaci mezi učitelem a žákem a je dobře aplikovatelný i v rámci zdravotně orientované tělovýchově. Dochází při něm k postupné přeměně záměrů pedagoga v jednání žáka. To by mělo mít za následek postupnou změnu jeho stavu. Nelze tento proces chápat jako jednosměrný, protože při něm dochází k oboustrannému působení. Účelem ovlivňování postiženého žáka je jeho motivování k učební činnosti.

Orientaci v problematice tělovýchovných aktivit přehledně zobrazuje následující obrázek, který ukazuje i potřebnou kvalifikaci příslušného tělovýchovného pracovníka. 
Tabulka 2: Rozdělení tělovýchovných a pohybových aktivit ve škole

\begin{tabular}{|l|l|l|l|l|}
\hline & $\begin{array}{l}\text { Tělesná } \\
\text { výchova (TV) }\end{array}$ & $\begin{array}{l}\text { Zdravotní tělesná } \\
\text { výchova (ZTV) }\end{array}$ & $\begin{array}{l}\text { Lécobná tělesná } \\
\text { výchova (LTV) }\end{array}$ & $\begin{array}{l}\text { Pohybové } \\
\text { terapie }\end{array}$ \\
\hline Aprobace & učitel TV & učitel ZTV & $\begin{array}{l}\text { fyzioterapeut, } \\
\text { kinezioterapeut }\end{array}$ & $\begin{array}{l}\text { speciální a } \\
\text { léčebný pedagog }\end{array}$ \\
\hline Oslabení & ne & ano & ano & ano \\
\hline Forma & skupinová & $\begin{array}{l}\text { individuální/ } \\
\text { skupinová }\end{array}$ & individuální & $\begin{array}{l}\text { individuální/ } \\
\text { skupinová }\end{array}$ \\
\hline
\end{tabular}

Zdroj: vlastní zpracování

Aktivity, které využívají pohyb a které nacházejí uplatnění ve speciální pedagogice jsou označeny jako přizpůsobené pohybové aktivity. Jsou to ty aktivity, jejichž snahou je nejen posilování fyzického zdraví, ale především posilování emoční inteligence a jejích složek. Podle věku se dělí na přizpůsobené pohybové aktivity pro kojence, batolata, předškoláky, školáky, dospívající a dospělé jedince. Podle druhu postižení pak lze hovořit o přizpůsobených pohybových aktivitách pro osoby s tělesným postižením, se zrakovým postižením, se sluchovým postižením a s mentálním postižením.

\subsection{Taneční a pohybové terapie}

Dramaterapie je expresivní druh terapie, poskytuje tedy možnost ventilace pocitů, sebevyjádření, poznání sebe i ostatních, získávání pozitivních zkušeností. Poskytuje možnost prostřednictvím konkrétní dramatické metafory vstoupit do příběhu a identifikovat se s postavou. Využívá aktivní i pasivní dramatické metody, které podporují kreativitu a dokáží prohlubovat vnitřní osobní život a zkušenosti člověka.

Nejvyužívanější v dramaterapii je hra a herní technika. Hra je nejčastěji zaměřena na individuálního jedince s důrazem na terapeutický vztah. Při dramaterapii dochází k rozvoji pohybová aktivity, verbální i neverbální komunikace. Dramaterapii s oblibou využívají nemocnice, školy, domovy a ústavy sociálních služeb, psychiatrické léčebny a věznice. Cíle dramaterapie se rozdělují na dvě základní skupiny. Ke všeobecným cílům patří zaměření na rozvoj zdravých aspektů žáka, na rozvoj představivosti a intuice a trénink sociálních dovedností. Dlouhodobější cíle se zaměřují na redukci vnitřního napětí, zvyšování odolnosti vůči stresu, socializaci, zvyšování sebevědomí a sebehodnocení (Krahulcová 2017).

Pohyb je i základním výrazovým prostředkem člověka, jazykem jeho pocitů a nálad, je prvotní formou prastaré lidské komunikace. Mnohé netradiční pohybové programy se k tomuto základnímu výrazovému prostředku vracejí (Mužík 1997).

Taneční a pohybové terapie využívají pohyb jako hlavní komunikační prostředek. Terapeutický proces je strukturovaný, veškerou aktivitu nechává na žákovi a na jeho projevy v rámci struktury odpovídá opět pohybem. Terapie se snaží odstranit bloky v chování, pohybu i v psychomotorickém vývoji žáka. Taneční terapie je dobře využitelná pro žáky s poruchami autistického spektra, žáky s poruchami příjmu potravy a s poruchami tělesného sebeobrazu, při potížích s koncentrací pozornosti nebo emočních poruchách, pro žáky s depresivními a úzkostnými poruchami a řadu dalších. Mezi taneční terapie patří například bazální tanec, který je založený na sdělování pocitů v kontextu skupinové pohybové interakce, Body - ego techniku, která vychází z moderního tance a pantomimy a jejíž hlavní složku představuje zrcadlení, tedy co nejpřesnější napodobování postojů, pohybů a držení těla založené na důkladném pozorování. (Dosedlová 2012). Dalšími technikami terapeutického tance je primitivní exprese, která je inspirovaná původními kmenovými tanci doprovázenými hrou na buben (Schott-Billmann 1991), a psychobalet, metoda, která v sobě spojuje základní výcvik baletních dovedností s psychoterapeutickými technikami (Cruzová1985).

\section{Strategie školy Euroinstitut}

Pohybové aktivity postižených žáků Euroinstitutu se rozdělují na několik skupin, ze kterých lze vybrat organizaci speciálně olympijských soutěží. Nejde o jedinou činnost, kromě školní tělovýchovy do sportovních činností patří i habituální pohybové aktivity, tedy pohybové činnosti denního života jako chůze, práce na zahradě, úklid nebo nákup.

Léčebná tělesná výchova je aktivita určená pro jedince s pozměněným zdravotním stavem, kterou předepisuje lékař a kterou realizuje lékař nebo fyzioterapeut a u řady našich žáků je i při pohybových aktivitách nutná lékařská supervize. 
Olympiády pořádají školy v rámci vzdělávání, mohou však fungovat i v zájmových sdruženích nebo sportovních oddílech za předpokladu, že je povedou pedagogové s odpovídajícím vzděláním, profesionální cvičitelé a trenéři. Sjednocené sporty v rámci Hnutí speciálních olympiád jsou klasickým př́íkladem integrace: v jednom týmu spolu nastupují sportovci s mentálním postižením a hráči bez handicapu. Partnerská organizace Euroinstitutu - Slunce není škola, pojímá klub speciálních olympiád jako rekreační sport postižených, který zahrnuje pohybové aktivity. Jde tak o složku volného času a životního stylu, stejně jako například plavání, turistika, cyklistika nebo veškeré druhy kolektivních sportů. Na rozdíl od jiných volnočasových aktivit klub speciálních olympiád vykazuje integrativní přístup v rámci organizací pečující o různá postižení.

\section{Diskuse}

Spolupráce domovů pro osoby se zdravotním postižením a školy se ukazuje jako úspěšná cesta s výrazným potenciálem. V první řadě proto bylo navrženo navázat na dosažené úspěchy a spolupráci výrazně zintenzivnit. Zájmové a terapeutické aktivity, které škola nabízí, je možno rozšśřit a nabídnout je i ostatním klientům domovů, kteří školu nenavštěvují. Škola ve spolupráci s domovy může pořádat soutěže mezi žáky z jednotlivých domovů, v pokročilé fázi i soutěže s dalšími školami.

V rámci zlepšení možností v oblasti sportování handicapovaných bylo navrženo založení klubu Speciálních olympiád, které by bylo společným krokem domovů pro osoby se zdravotním postižením a školy pro žáky se speciálními vzdělávacími potřebami. Založení klubu přinese hned několik pozitivních změn. Hnutí Speciálních olympiád přináší kromě běžných sportovních disciplín také přizpưsobené pohybové aktivity. To je soutěžní program určený začátečníkům nebo velmi mladým sportovcům, kteří se soutěžním sportem začínají, nebo sportujícím s intenzivnějšími limity (Speciální olympiády Česká republika, 2021). Kluby Speciálních olympiád se dokáží vyrovnat s potřebou individuálních potřeb sportovců. Vzhledem ke svému zapojení do Hnutí speciálních olympiád dokáže své sportovce zapojit do celorepublikových, ale i mezinárodních soutěží. Tento fakt představuje výrazný motivační faktor pro handicapované sportovce.

Zvýšené úsilí školy a domovů, sportovní zápolení, soutěže i turnaje, ale i pravidelné snažení handicapovaných je vhodné pravidelně zaznamenávat. Ze záznamů obrazových i videozáznamů lze zpracovat propagační materiál, který pomůže osvětě na téma organizovaný sport handicapovaných. V rámci zvyšování povědomí o organizacích, které se zabývají sportem handicapovaných, dále bylo navrženo navazování spolupráce s dalšími domovy pro osoby se zdravotním postižením a s dalšími ústavy sociální péče.

\section{Závěr}

Cílem byl návrh strategie ke zkvalitnění služeb poskytovaných handicapovaným žákům v oblasti pohybových aktivit. Na základě vlastních zkušeností byla nastíněna strategie vytvoření programu, jehož základem je úzká spolupráce subjekto̊, které se na péči a vzdělávání handicapovaných podílejí, v tomto případě spolupráce školy pro žáky se speciálními vzdělávacími potřebami a domovů, ze kterých žáci do školy docházejí. Jako logické vyústění spolupráce se jeví společné založení sportovního klubu, ideálně klubu Speciálních olympiád, který nabízí takové možnosti jako zapojení do systému soutěží na úrovni republikové i mezinárodní.

\section{Literatura}

CRUZOVÁ, D. Psychobalet a možnosti aplikace metody aktivního sociálního učení při práci s tělesně postiženými dětmi na Kubě. Československá psychologie. 1985, roč. 29, č. 1, s. 93-95. ISSN 0009-062X

ČERNÁ, Marie (Ed.). 2015, Česká psychopedie. Praha: Univerzita Karlova. 2015, ISBN 978-80-246-3071-7.

DOSEDLOVÁ, Jaroslava. Terapie tancem: role tance v dějinách lidstva a v současné psychoterapii. Praha: Grada, 2012. Psyché (Grada). ISBN 978-80-247-3711-9.

KRAHULCOVÁ, Kristýna. 2017. Využití dramaterapie na detoxikačním oddělení. Olomouc: Univerzita Palackého v Olomouci, 2017. ISBN 978-80-244-5275-3.

KREJČÍ, František. 1991. Obecné základy pedagogiky. Ostrava: Ostravská univerzita. 1991. ISBN 80-7042041-3.

LEVITOVÁ, Andrea a Blanka HOŠKOVÁ. 2015. Zdravotně-kompenzační cvičení. Praha: Grada Publishing, 2015. ISBN 978-80-247-4836-8. 
MUŽÍK, Vladislav a Milada KREJČĆ. 1997. Tělesná vǵchova a zdraví: zdravotně orientované pojetí tělesné výchovy pro 1. stupeň ZŠ. Olomouc: Hanex, 1997. Tělesná výchova a zdraví. ISBN 80-85783-17-7.

PROCHÁZKA, Boris. 2017. Z historie speciální tělesné výchovy. Školské poradenské zařízení SPC: Portál speciální pedagogika [online]. Slaný, 5. 9.2017 [cit. 2021-01-26]. Dostupné z: https://www.specialni-pedagogika.cz/z-historie-specialni-telesne-vychovy/

Sdělení č. 10/2010 Sb. mezinárodních smluv Ministerstva zahraničních věcí, o sjednání Úmluvy o právech osob se zdravotním postižením."

Speciální olympiády Česká republika. 2021. In: Facebook [online]. [cit. 2021-09-15]. Dostupné z: https:// www.facebook.com/SpecialniOlympiada/

SCHOTT-BILLMANN, F. L’expression primitive. Lien social. 1991, č. 114, s.5-7. ISSN 1204-3206.

ŠERÁKOVÁ, Hana. 2009. Cvičím pro zdraví a baví mě to. 1. vyd. Brno: Masarykova univerzita, 2009. ISBN 978-80-210-4833-1.

ŠVEC, Štefan. 2003. K etickému kodexu učitelskej profesie. In: Spravodaj SPS pri SAV. Trnava: Slovenská pedagogická spoločnosti pri SAV, 2003, II(4), 1-6.

WEIGNER, Karel. 1916. Tělesná výchova: její význam a cesty. Praha: Jos. R. Vilímek, 1916. 39 s.

Zákon č. 108/2006 Sb., o sociálních službách.

\section{Informace o autorce}

\section{Exseil Streda}

Speciální pedagog Střední školy Euroinstitut zaměřený na praktické vyučování a mimoškolní aktivity postižených žáků 